\title{
Ovarian response to $\mathrm{hCG}$ treatment during the oestrous cycle in heifers*
}

\author{
C. A. Price $†$ and R. Webb \\ Institute of Animal Physiology \& Genetics Research, Edinburgh Research Station, \\ Department of Reproduction and Growth, Roslin, Midlothian EH25 9PS, UK
}

\begin{abstract}
Summary. The aims of this study were to investigate whether treatment with a single ovulatory dose of hCG, between the day of oestrus and the end of the luteal phase, could induce extra ovulations in heifers and whether the presence of an existing corpus luteum $(\mathrm{CL})$ affected the response. Heifers $(\mathrm{N}=32)$ were injected with 1500 i.u. hCG or saline on a given day of the oestrous cycle. Treatments were repeated during subsequent cycles to provide a total of 71 observations, 57 of which followed an injection of hCG, given between Day 0 (oestrus) and Day 16, and 14 of which followed saline injections as controls. Ovulatory responses were noted by laparoscopy 2 days after hCG treatment. No heifers injected with saline produced additional CL. Of the hCGtreated cycles, 23 resulted in the formation of an additional $\mathrm{CL}$, and this was significantly affected by the stage of the oestrous cycle when hCG was given; a greater response was observed during the early (Days 4-7) and late (Days 14-16) stages of the luteal phase than at the mid-luteal phase of the oestrous cycle. Two heifers were also treated with hCG on Days 17 or 18 of the oestrous cycle, but before oestrus; both had induced CL. There were no significant differences between the left-right orientation of the existing CL or the hCG-induced CL.

These results demonstrate that the large, luteal-phase follicle of the cow is capable of ovulating in response to $\mathrm{hCG}$ and that the induced $\mathrm{CL}$ is not affected by the presence of an existing CL.
\end{abstract}

Keywords: cattle; ovulation; hCG; follicle; luteal phase

\section{Introduction}

The hypothesis that the corpus luteum (CL) plays a role in the control of ovarian follicular growth in ruminants is controversial. Most studies have examined changes in follicular populations in ovaries with or without a CL, either by dissection or by ultrasonography, rather than investigating the functional ability of large follicles present during the luteal phase.

It is known that large luteal-phase follicles have receptors for both LH and FSH on the granulosa cell layer (sheep: England et al., 1981; cattle: Ireland \& Roche, 1983), and are capable of secreting significant quantities of oestradiol (sheep: Baird et al., 1976; cattle: Skyer et al., 1987); in this, they are similar to preovulatory follicles present during the follicular phase. However, whilst removal or regression of the CL leads to ovulation, the follicles that ovulate may not necessarily be the large follicles present at the time of luteolysis (Ireland \& Roche, 1982; Driancourt \& Cahill, 1984).

Previous studies have been reviewed to demonstrate that there are at least three major periods of increased oestradiol secretion, primarily from mature follicles (Ireland \& Roche, 1987). In

*Reprint requests to Dr R. Webb.

†Present address: MAFTech Wallaceville Animal Research Centre, P.O. Box 40063, Upper Hutt, New Zealand. 
addition, daily ultrasound examinations have shown that there are usually three periods during the oestrous cycle when dominant follicles are present (Savio et al., 1988; Sirois \& Fortune, 1988). These data are corroborated by the finding that the concentration of receptors for LH on granulosa cells is higher during the early luteal phase, Day 7, than during the mid-luteal phase, Day 13 (Ireland \& Roche, 1983).

The aim of the present study was to assess the ability of large follicles in cattle to ovulate in response to $\mathrm{hCG}$, and to determine whether this response was affected by the presence of an existing $\mathrm{CL}$ or by stage of the oestrous cycle.

\section{Materials and Methods}

Animals. The 32 Hereford Friesian crossbred heifers, $\sim 2$ years of age, used in this study were kept on Institute farms in Scotland. The heifers were maintained outdoors under standard husbandry conditions. Observations for behavioural oestrus were made at least twice daily, aided by a heat detection device (Kamar Inc., Steamboat Springs, CO, USA).

Treatments. The animals were randomly assigned to receive a single $5 \mathrm{ml}$ intravenous injection of 1500 i.u. hCG (Chorulon; Intervet, Cambridge, UK) or saline $(0.154 \mathrm{M}-\mathrm{NaCl})$ on a specified day of the oestrous cycle. This dose was chosen because 1500-2000 i.u. hCG has been commonly used to control the time of ovulation in cattle (see Hunter, 1980). The ovulatory response was examined by sublumbar laparoscopy 2 days after hCG injection; the location of the existing CL, and the number and location of any induced CL were recorded. For laparoscopy the heifers were fasted for up to $48 \mathrm{~h}$. Animals were then lightly sedated $(0.75 \mathrm{ml}$ i.m. Rompun; Baker UK Ltd, Bury St Edmunds, Suffolk, UK) and the area of incision was locally anaesthetized by infiltration with $5 \mathrm{ml} 2 \%$ lignocaine (Lignocaine-A; Univet 2 Ltd, Bicester, Oxon, UK). After observations, a topical antibiotic was applied to the incision. After the first treatment cycle, animals then underwent an oestrous cycle without treatment before being randomly reassigned to receive a second dose of $1500 \mathrm{i}$.u. hCG or saline on an alternative day of the third oestrous cycle. Finally, some of the heifers were treated during the fourth oestrous cycle of the experiment. Overall, 14 heifers were treated 3 times, 16 heifers twice, and 2 animals were treated once only. On three occasions the ovaries were not observed due to the extension of the rumen into the peritoneal cavity, but of the remaining 73 observations, 59 were after hCG treatment and 14 were after saline injections.

Data analysis. The data were analysed by contingency table and $\chi^{2}$ tests, with Yates' correction where necessary. The results were grouped into the following stages of the oestrous cycle: peri-oestrous phase, Days 0-3; early luteal phase, Days 4-7; mid-luteal phase, Days 8-13 and the late-luteal phase, Days 14-16. The divisions used in the present study were based on published hormonal and morphological data. The period from the day of oestrus to Day 3 has been termed the peri-oestrous phase since the animal is neither follicular nor truly luteal. The early luteal phase covers the period when plasma progesterone concentrations have started to rise, but have not reached a plateau (Wetteman et al., 1972; Milvae \& Hansel, 1983). A 'wave' of follicular growth has been reported at this time (Matton et al., 1981), and also an elevation in mean FSH concentrations (Schams \& Schallenberger, 1976). The mid-luteal phase has been characterized as having a fairly stable follicle population (Matton et al., 1981) and high circulating progesterone concentrations (Schams \& Schallenberger, 1976; Milvae \& Hansel, 1983). The late-luteal phase can be said to start when the CL begins to regress (Hafez \& Sugie, 1963), but whilst progesterone concentrations remain high (Schams et al., 1977). A fresh wave of follicle growth was reported at this time (Matton et al., 1981; Pierson \& Ginther, 1987a). Of less importance to the present study is the follicular phase, which occurs from luteolysis until ovulation. Two of the heifers were treated with hCG on Days 17 or 18 of the cycle, but before oestrus, and both had induced CL. The results of these 2 animals were not included in the data analysis.

\section{Results}

No corpora lutea were induced in heifers injected with saline at any stage of the oestrous cycle, as judged by the age of the single CL observed at laparoscopy (Ireland et al., 1980). Of the 57 cycles treated with hCG from Days 0 to 16 of the oestrous cycle, 23 resulted in the formation of induced CL (Table 1). The induced CL were easily distinguished from the existing CL during the luteal phase, as being bright red in colour and usually smaller in size. Ovulation points were also clearly visible. However, 2 of the heifers treated during the peri-oestrous period (1-2 days after oestrus) had two CL, but it was not possible to distinguish which $C L$ had been induced by the hCG treatment and which had been induced by the preovulatory LH surge. It is likely that one of the CL had 
been produced by the treatment, firstly because none of the controls had double ovulations and, secondly, the twinning rate in cattle is naturally low.

There was a significant effect of the stage of the oestrous cycle on the proportion of heifers producing induced CL (Table $1 ; \chi^{2}=18.2$, d.f. $=3 ; P<0.001$ ), and this effect remained significant even when only the different stages of the luteal phase (early, mid-and late) were compared $\left(\chi^{2}=7 \cdot 5\right.$, d.f. $\left.=2 ; P<0.05\right)$. Before treatment all existing ovulations were singles, whereas two induced ovulations were doubles, one unilateral (late luteal phase) and one bilateral (early luteal phase). There appeared to be no carry-over effect of repeated hCG injections as treatment between the 2nd and 3rd treatment cycles had no significant effect on oestrous cycle length (controls: $20 \cdot 2 \pm 0.5$ days $(\mathrm{N}=4)$; hCG treatment with induced $\mathrm{CL}: 21 \cdot 3 \pm 1.6$ days $(\mathrm{N}=12)$; hCG treatment with no induced $\mathrm{CL}: 19 \cdot 2 \pm 0.9$ days $(\mathrm{N}=9)$ ). Furthermore, 8 heifers, given saline after treatment with hCG during a previous cycle, had single ovulations. Although the first and second treatment oestrous cycles were separated by an oestrous cycle to reduce any possible carry-over effect of successive treatments, 16 animals were treated during succeeding cycles (oestrous cycles 3 and 4). In these 16 heifers there was no obvious trend as 3 heifers had induced CL in both cycles; 5 heifers had induced CL during the 3 rd cycle, but no induced CL in the 4th cycle; 4 heifers had induced CL during the 4th cycle, but none on the 3 rd cycle; and 4 heifers had no induced CL in either cycle. Moreover, in all subsequent oestrous cycles after the first treatment with hCG, regardless of the treatment of that cycle, all heifers had shown single, morphologically healthy corpora lutea produced at natural oestrus and ovulations; this indicates that previous hCG treatment did not affect the growth of preovulatory follicles.

Table 1. Effect of the stage of the oestrous cycle* on the number of heifers ovulating in response to 1500 i.u. hCG

\begin{tabular}{lcccc}
\hline & $\begin{array}{c}\text { Peri-oestrus } \\
\text { (Days 0-3) }\end{array}$ & $\begin{array}{c}\text { Early luteal } \\
\text { (Days 4-7) }\end{array}$ & $\begin{array}{c}\text { Mid-luteal } \\
\text { (Days 8-13) }\end{array}$ & $\begin{array}{c}\text { Late luteal } \\
\text { (Days 14-16) }\end{array}$ \\
\hline $\begin{array}{l}\text { No. of control heifers treated with saline† } \\
\begin{array}{l}\text { No. of heifers treated with hCG } \\
\text { No. (\%) of hCG-treated heifers with } \\
\text { induced CL }\end{array}\end{array}$ & 6 & 3 & 3 & 2 \\
$\begin{array}{l}\text { Mean no. of induced CL per heifer } \\
\text { responding to hCG }\end{array}$ & 19 & 12 & 20 & 6 \\
\hline
\end{tabular}

$*$ Day $0=$ oestrus.

$\dagger$ All control heifers had a single ovulation.

a versus $\mathrm{b}$ are significantly different $(P<0.001)$.

Existing CL were equally distributed between right and left ovaries $(42 \cdot 3 \%$ left, $57 \cdot 7 \%$ right; $P>0.05$ ). Similarly, $\mathrm{CL}$ induced by hCG treatment were equally distributed between right and left ovaries (40.7\% left, $59.3 \%$ right; $P>0.05$ ). There was no significant effect of (i) the left/right orientation of the existing $\mathrm{CL}$ on the number of heifers responding to the hCG $(P=0 \cdot 7$; d.f. $=1)$; (ii) the left/right orientation of the existing CL on that of the induced CL $(P=0.87$; d.f. $=1)$; (iii) the left/right orientation of the existing CL on the tendency of the induced CL to occur in the same ovary $(P=0.34$; d.f. $=1)$; (iv) the stage of the oestrous cycle on the occurrence of induced CL in the existing CL-bearing ovary $(P=0 \cdot 29$; d.f. $=3)$; or $(v)$ the stage of the oestrous cycle on the left/right orientation of the induced CL $(P=0.69$; d.f. $=3)$.

\section{Discussion}

These results show that the large, luteal-phase follicle of the cow is capable of responding to hCG to produce a luteinized structure which at the level of the laparoscope is not distinguishable from a 
normal CL. Presumably, therefore, the large luteal-phase follicle is capable of ovulating in response to an LH surge, for although follicular status was not assessed before hCG injection, previous studies of cattle follicular populations suggest that large follicles are present throughout most of the luteal phase of the oestrous cycle (Matton et al., 1981; Pierson \& Ginther, 1987a; Savio et al., 1988; Sirois \& Fortune, 1988). The functional ability of the hCG-induced CL was not assessed in the present experiment. The hCG-induced CL appeared to be smaller than the existing CL, but this may have been an effect of the age of the CL. Peripheral progesterone concentrations were not measured in this study, because the functional ability of the CL would have to be assessed by in-vitro progesterone production since there are no significant differences in peripheral progesterone concentrations between single and twin-ovulating animals (Morris et al., 1987). However, the presence of an hCG-induced CL, particularly during the late-luteal phase, did not extend the length of the oestrous cycle compared with either control heifers or treated heifers with no extra ovulations. Usually, the $\mathrm{CL}$ of cattle are unresponsive to luteolysis until at least Day 5 after ovulation (Rowson et al., 1972; Hafs \& Manns, 1975), and this indicates that the induced CL were not actually fully functional.

The results in the present study have allowed a new approach to the examination of an old problem. Previous work has suggested that the ovary bearing the CL has a higher number of follicles than the contralateral ovary in sheep and cattle (Dufour et al., 1971; Matton et al., 1981; Pierson \& Ginther, 1987b; Savio et al., 1988), and that the diameter of the large luteal-phase follicle is greatest (Dufour et al., 1971; Staigmiller \& England, 1982), and the follicle more oestrogenic (England et al., 1973) when positioned ipsilateral rather than contralateral to the CL. However, other authors have reported that the location of the $\mathrm{CL}$ has no effect upon antral follicle distribution (Ireland et al., 1979), and that the diameter of the large follicle is smaller when in the CL-bearing ovary (Matton et al., 1981). Hunter \& Southee (1987) reported that progesterone has a direct effect upon the sheep ovary, decreasing oestradiol secretion from large follicles, but increasing the ability of hCG to bind to the thecal cells. The present data indicate that the existing CL has no significant effect upon the orientation or distribution of follicles capable of responding to hCG. This is in agreement with the frequency of bilateral and unilateral double ovulations observed in a herd of cattle selected for high twinning rate (Morris \& Day, 1987), and may support the data of Al-Gubory \& Martinet (1987), who suggest that the CL only affects preantral follicle distribution. Any progesterone effect (Hunter \& Southee, 1987) would therefore have to be mediated via the peripheral circulation. Our results also suggest that the angiogenic activity of cattle CL (Redmer et al., 1988) does not play a role in the development of large follicles.

The response of the heifers in this study was significantly affected by the period of the luteal phase at which the hCG was given; animals were more responsive during Days 4-7 and 14-16 than they were from Days 8 to 13 (Table 1). These data are corroborated by the higher concentration of receptors for $\mathrm{LH}$ on the granulosa cells during the early luteal phase (Day 7) than during the midluteal phase (Day 13) in cattle (Ireland \& Roche, 1983); the concentrations of receptors for FSH appear to remain constant throughout the cycle (Staigmiller et al., 1982; Ireland \& Roche, 1983). It has also been reported that 'waves' of large follicle growth occur during the early and late luteal phases of the oestrous cycle (Matton et al., 1981; Pierson \& Ginther, 1987a; Savio et al., 1988; Sirois \& Fortune, 1988). The increases in the responsiveness to hCG at the different periods of the luteal phase observed in the present study therefore appear to coincide with the presence of large follicles that have been reported elsewhere. The lower response during the mid-luteal phase may reflect an absence of follicles at an adequate stage of maturity; for example, sufficient granulosa cell LH receptors (Ireland \& Roche, 1983). In addition over $70 \%$ of cattle injected with a luteolytic dose of PGF- $2 \alpha$ on Days 11 and 12 of the oestrous cycle took 4-5 days to exhibit oestrus, compared with 48-72 $\mathrm{h}$ in animals injected on Days 7 or 16 (MacMillan \& Henderson, 1983/4). This response was interpreted as reflecting a wave-like pattern in ovarian follicle development, with the presence of less mature follicles during the mid-luteal phase. However, a lower proportion of cattle did have induced ovulations during the mid-luteal phase possibly due in part to the fact that $20-30 \%$ of 
heifers have 1, 2 or 4 dominant follicles per cycle (Savio et al., 1988; Sirois \& Fortune, 1988), rather than 3. This may also, in part, account for the fact that not all heifers during the early or late luteal phases of the cycle had induced CL.

In conclusion, these results show that the large luteal-phase follicle is capable of responding to $\mathrm{hCG}$, and that this response is lower when the hCG was given in the mid-luteal phase than in the early or late luteal phases. In addition, the data suggest that the corpus luteum per se does not exert a local constraint on the growth of 'potentially-ovulatory' follicles.

We thank the staff of Blythbank Farm for husbandry of cattle, recording of oestrus and assistance in surgery; and D. McGavin and W. Ritchie for assistance with anaesthesia.

\section{References}

Al-Gubory, K.H. \& Martinet, J. (1987) Effect of the corpus luteum on ovarian follicular populations and growth in the ewe. Anim. Reprod. Sci. 13, 269-281.

Baird, D.T., Swanston, I. \& Scaramuzzi, R.J. (1976) Pulsatile release of $\mathrm{LH}$ and secretion of ovarian steroids in sheep during the luteal phase of the estrous cycle. Endocrinology 98, 1490-1496.

Driancourt, M.A. \& Cahill, L.P. (1984) Preovulatory folliclar events in sheep. J. Reprod. Fert. 71, 205-211.

Dufour, J., Ginther, O.J. \& Casida, L.E. (1971) Corpus luteum action on ovarian follicular development after destruction of macroscopically visible follicles in ewes. Proc. Soc. exp. biol. Med. 138, 475-478.

England, B.G., Hauser, E.R. \& Casida, L.E. (1973) Some effects of unilateral ovariectomy in the post-partum beef cow. J. Anim. Sci. 36, 45-50.

England, B.G., Webb, R. \& Dahmer, M.K. (1981) Follicular steroidogenesis and gonadotropin binding to ovine follicles during the estrous cycle. Endocrinology $109,881-887$.

Hafez, E.S.E. \& Sugie, T. (1963) Behavioural oestrus and ovulatory cycle in beef cattle with a note on the clay model technique. Acta zool., Stockh. 44, 57-71.

Hafs, H.D. \& Manns, J.G. (1975) Onset of oestrus and fertility of dairy heifers and suckled beef cows treated with prostaglandin $\mathrm{F}_{2 \alpha}$. Anim. Prod. 21, 13-20.

Hunter, M.G. \& Southee, J.A. (1987) Treatment with progesterone affects follicular steroidogenesis in anoestrous ewes. Anim. Reprod. Sci. 14, 273-279.

Hunter, R.H.F. (1980) Physiology and Technology of Reproduction in Female Domestic Animals, pp. 64 103. Academic Press, London.

Ireland, J.J. \& Roche, J.F. (1982) Development of antral follicles in cattle after prostaglandin-induced luteolysis: changes in serum hormones, steroids in follicular fluid, and gonadotropin receptors. Endocrinology 111, 2077-2085.

Ireland, J.J. \& Roche, J.F. (1983) Development of non-ovulatory antral follicles in heifers: changes in steroids in follicular fluid and receptors for gonadotropins. Endocrinology 112, 150-156.

Ireland, J.J. \& Roche, J.F. (1987) Hypotheses regarding development of dominant follicles during a bovine oestrous cycle. In Follicular Growth and Ovulation Rate in Farm Animals, pp. 1-18. Eds J. F. Roche \& D. O'Callaghan. Martinus Nijhoff, Dordrecht.

Ireland, J.J., Coulson, P.B. \& Murphree, R.L. (1979) Follicular development during four stages of the estrous cycle of beef cattle. J. Anim. Sci. 49, 1261-1269.
Ireland, J.J., Murphree, R.L. \& Coulson, P.B. (1980) Accuracy of predicting stages of bovine estrous cycle by gross appearance of the corpus luteum. J. Dairy Sci. 63, 155-160.

Macmillan, K.L. \& Henderson, H.V. (1983/1984) Analysis of the variation in the interval from an injection of prostaglandin $F_{2 \alpha}$ to oestrus as a method of studying patterns of follicle development during dioestrus in dairy cows. Anim. Reprod. Sci. 6, 245-254.

Matton, P., Adelakoun, V., Couture, Y. \& Dufour, J.J. (1981) Growth and replacement of the bovine ovarian follicles during the estrous cycle. J. Anim. Sci.52, 813-820.

Milvae, R.A. \& Hansel, W. (1983) Prostacyclin, prostaglandin $F_{2 \alpha}$ and progesterone production by bovine luteal cells during the estrous cycle. Biol. Reprod. 29, 1063-1068

Morris, C.A. \& Day, A.M. (1987) Ovulation and calving data in a twin breeding experiment. Proc. Aust. Soc. Reprod. Biol. 19, 29, Abstr.

Morris, C.A., Day, A.M. \& Peterson, A.J. (1987) Effects of ovulation status and stage of oestrous cycle on plasma progesterone concentrations in cattle with or without a history of twin calvings. Anim. Prod. 45, 205-209.

Pierson, R.A. \& Ginther, O.J. (1987a) Follicular populations during the estrous cycle in heifers. I. Influence of day. Anim. Reprod. Sci. 14, 165-176.

Pierson, R.A. \& Ginther, O.J. (1987b) Follicular populations during the estrous cycle in heifers. II. Influence of right and left sides and intraovarian effect of the corpus luteum. Anim. Reprod. Sci. 14, $177-186$.

Redmer, D.A., Grazul, A.T., Kirsch, J.D. \& Reynolds, L.P. (1988) Angiogenic activity of bovine corpora lutea at several stages of luteal development. $J$. Reprod. Fert. 82, 627-634.

Rowson, L.E.A., Tervit, R. \& Brand, A. (1972) Synchronization of oestrus in cattle by means of prostaglandin $\mathrm{F}_{2 \mathrm{a}}$. Proc. 7th Int. Congr. Anim. Reprod. \& A.I., Munich 2, 865-867.

Savio, J.D., Keenan, L., Boland, M.P. \& Roche, J.F. (1988) Pattern of growth of dominant follicles during the oestrous cycle of heifers. J. Reprod. Fert. 83, $663-671$.

Schams, D. \& Schallenberger, E. (1976) Heterologous radioimmunoassay for bovine follicle-stimulating hormone and its application during the oestrous cycle in cattle. Acta endocr., Copenh. 81, 461-473. 
Schams, D., Schallenberger, E., Hoffmann, B. \& Karg, H. (1977) The oestrous cycle of the cow: hormonal parameters and time relationships concerning oestrus, ovulation, and electrical resistance of the vaginal mucus. Acta endocr., Copenh. 86, 180-192.

Sirois, J. \& Fortune, J.E. (1988) Ovarian follicular dynamics during the estrous cycle in heifers monitored by real-time ultrasonography. Biol. Reprod. 39, 308317 .

Skyer, D.M., Garverick, H.A., Youngquist, R.S. \& Krause, G.F. (1987) Ovarian follicular populations and in vitro steroidogenesis on three different days of the bovine estrous cycle. J. Anim. Sci. 64, 1710-1716.
Staigmiller, R.B. \& England, B.G. (1982) Folliculogenesis in the bovine. Theriogenology 17, 43-52.

Staigmiller, R.B., England, B.G., Webb, R., Short, R.E. \& Bellows, R.A. (1982) Estrogen secretion and gonadotropin binding by individual bovine follicles during estrus. J. Anim. Sci. 55, 1473-1482.

Wettemann, R.P., Hafs, H.D., Edgerton, L.A. \& Swanson, L.V. (1972) Estradiol and progesterone in blood serum during the bovine estrous cycle. J. Anim. Sci. 34, $1010-1024$.

Received 19 September 1988 